\title{
Improving Student Learning Outcomes Through Video Aided Problem Based Learning Model
}

\section{Ria Titis Pratiwi}

\author{
SD Negeri 05 Bantarbolang,Pemalang
} anandyatitis@gmail.com

\section{Article History}

accepted $14 / 11 / 2020$

\begin{abstract}
This study aims to improve the learning outcomes of the third grade students of SD Negeri 05 Bantarbolang on the sub-theme of Aneka Benda around me through a video-assisted problembased learning model. This research is a Classroom Action Research (PTK) which consists of three cycles, where each cycle is carried out in one face-to-face. The Action Plan for each cycle in the CAR is divided into four activities, namely Planning, Implementation, Observation, and Reflection. The data collection technique in this study is a formative test. The instrument used to collect data was a learning outcome test. Completeness of student learning outcomes in cycle I only reached $60 \%$ with a mean of 77 , in cycle II student learning completeness reached $87 \%$ with a mean of 81 , and in cycle III student learning completeness reached $87 \%$ with a mean of 83. The results of this study indicate that the application of the learning model video-assisted problem-based learning can improve student learning outcomes.
\end{abstract}

Keywords: learning outcomes, learning models, problem based laerning, video media

\begin{abstract}
Abstrak
Penelitian ini bertujuan untuk meningkatkan hasil belajar siswa kelas III SD Negeri 05 Bantarbolang pada subtema Aneka Benda di Sekitarku melalui model pembelajaran problem based learning berbantuan video. Penelitian ini merupakan Penelitian Tindakan Kelas (PTK) yang terdiri atas tiga siklus.Dimana setiap siklus dilaksanakan dalam satu kali tatap muka. Rencana Tindakan pada masing-masing siklus dalam PTK ini dibagi dalam empat kegiatan yaitu Perencanaan, Pelaksanaan, Observasi, dan Refleksi. Teknik pengumpulan data pada penelitian ini adalah tes formatif. Instrumen yang digunakan untuk mengumpulkan data yaitu tes hasil belajar. Ketuntasan hasil belajar siswa pada siklus I baru mencapai $60 \%$ dengan rerata 77, pada siklus II ketuntasan belajar siswa mencapai $87 \%$ dengan rerata 81 , dan pada siklus III ketuntasan belajar siswa mencapai $87 \%$ dengan rerata 83 . Hasil penelitian ini menunjukkan bahwa penerapan Model pembelajaran problem based learning berbantuan video dapat meningkatkan hasil belajar siswa .
\end{abstract}

Kata kunci: hasil belajar, model pembelajaran, problem based laerning, media video

Social, Humanities, and Education Studies (SHEs): Conference Series https://jurnal.uns.ac.id/shes 


\section{PENDAHULUAN}

Belajar dari rumah (BDR) diterapkan oleh pemerintah dalam upaya untuk mengurangi penyebaran Covid-19. Hal ini memiliki pengaruh yang besar bagi dunia pendidikan. Hal ini disebabkan karena guru belum terbiasa dalam menerapkan model pembelajaran jarak jauh.

Pembelajaran jarak jauh yang dilakukan guru pada masa belajar dari rumah umumnya hanya melalui pesan singkat whatapp dengan memberikan penugasan-penugasan kepada siswa. Pembelajaran yang tidak intens menyebabkan beberapa permasalahan. Permasalahan yang muncul antara lain, pembelajaran kurang aktif dan interaktif, kurangnya pemanfaatan media pembelajaran, rendahnya motivasi belajar, hal ini menyebabkan masih rendahnya prestasi belajar siswa, ini ditunjukkan dari 15 siswa yang mengikuti evaluasi, hanya ada 5 siswa atau $33 \%$ siswa yang berhasil mencapai nilai 70 keatas atau dapat mencapai ketuntasan belajar. Sisanya ada 10 siswa atau $67 \%$ mendapat nilai 70 ke bawah atau belum mencapai ketuntasan belajar. Sedangkan untuk ketuntasan klasikal kelas III semester 1 SD Negeri 05 Bantarbolang adalah $80 \%$. Hal ini menunjukkan bahwa hasil hasil belajar siswa masih rendah.

Upaya yang dilakukan guru untuk meningkatkan prestasi belajar siswa belumlah maksimal. Untuk membantu siswa mendapatkan pemahaman materi yang baik maka peneliti merasa perlu untuk memberikan materi penunjang berupa video pembelajaran. Video pembelajaran disiapkan oleh guru dapat melaluai video yang sudah tersedia dan memiliki kesesuaian materi pelajaran yang sedang diajarkan atau guru dengan kreatifitasnya membuat sendiri video pembelajaran.

Pembelajaran berbasis video (Video based learning) yang akan diterapkan pada penelitian ini diharapkan dapat meningkatkan pemahaman materi siswa sehingga berdampak pada meningkatnya hasil belajar siswa. Hingga saat ini, riset, kajian dan studi literatur terkait video based learning masih marak dilakukan oleh para akademisi. Penerapan video based learning sangat relevan dengan proses pembelajaran pada zaman ini yang didominasi oleh generasi millenial dan generasi Z.

Pengertian belajar menurut Ngalim Purwanto (1990: 85) mengatakan bahwa belajar adalah merupakan suatu perubahan tingkah laku, di mana perubahan itu dapat mengarah kepada tingkah laku yang lebih baik, tetapi juga ada kemungkinan mengarah kepada tingkah laku yang lebih buruk. Selain itu belajar juga dapat diartikan sebagai perubahan yang terjadi karena latihan atau pengalaman. Dimyati dan Mudjiono (2006) : Belajar merupakan suatu proses internal yang kompleks, yang terlibat dalam proses internal tersebut adalah yang meliputi unsur afektif, dalam matra afektif berkaitan dengan sikap, nilai-nilai, interes, apresiasi, dan penyesuaian perasaan sosial. Selanjutnya pengertian hasil menurut Kamus Besar Bahasa Indonesia (1995: 343) adalah sesuatu yang diadakan (dibuat, dijadikan, dsb.) oleh usaha.

Dari pengertian di atas dapat disimpulkan bahwa hasil belajar merubahan pengetahuan, ketrampilan dan sikap dan nilai yang dipengaruhi oleh factor dari dalam maupun dari luar individu kearah perubahanyang lebih baik atau yang lebih maju.

Model pembelajaran merupakan landasan praktik pembelajaran hasil penurunan teori psikologi pendidikan dan teori belajar yang dirancang berdasarkan analisis terhadap implementasi kurikulum dan implikasinya pada tingkat operasional di kelas (Suprijono, 2013:45-46). Sedangkan menurut Komalasari (2013:57), Model pembelajaran merupakan bentuk pembelajaran yang tergambar dari awal sampai akhir yang disajikan guru. Model pembelajaran digunakan guru selama melakukan proses pembelajaran. 
Menurut Wisudawati dan Eka (2014:49), model pembelajaran merupakan kerangka konseptual yang melukiskan prosedur secara sistematis dalam mengorganisasikan pengalaman belajar untuk mencapai tujuan pembelajaran. Model pembelajaran juga merupakan implementasi dari suatu pendekatan, metode dan teknik dalam pembelajaran yang disusun secara sistematis dan dilaksanakan saat proses pembelajaran untuk mencapai tujuan pembelajaran.

Dari pemaparan beberapa ahli tersebut di atas dapat diambil kesimpulan bahwa model pembelajaran merupakan kerangkan konseptual dalam menerapkan pembelajaran yang akan dilakukan dari awal hingga akhir pembelajaran secara sistematis.

Model PBL dikembangkan berdasarkan konsep-konsep yang dicetuskan oleh Jerome Bruner. Konsep tersebut adalah belajar penemuan atau discovery learning. Konsep tersebut memberikan dukungan teoritis terhadap pengembangan model PBL yang berorientasi pada kecakapan memproses informasi.

Menurut Barbara J. Duch (1996), Problem Based Learning (PBL) adalah satu model yang ditandai dengan penggunaan masalah yang ada di dunia nyata untuk melatih siswa berfikir kritis dan terampil memecahkan masalah, dan memperoleh pengetahuan tentang konsep yang penting dari apa yang dipelajari (Wijayanto, 2009:15). Menurut Suyatno (2009), Problem Based Learning (PBL) merupakan suatu model pembelajaran yang berbasis pada masalah, dimana masalah tersebut digunakan sebagai stimulus yang mendorong mahasiswa menggunakan pengetahuannya untuk merumuskan sebuah hipotesis, pencarian informasi relevan yang bersifat student-centered melalui diskusi dalam sebuah kelompok kecil untuk mendapatkan solusi dari masalah yang diberikan. Problem Based Learning atau Pembelajaran Berbasis Masalah merupakan penggunaan berbagai macam kecerdasan yang diperlukan untuk melakukan konfrontasi terhadap tantangan dunia nyata, kemampuan untuk menghadapi segala sesuatu yang baru dan kompleksitas yang ada. Model pembelajaran problem based learning bertujuan membantu peserta didik untuk mengembangkan kemampuan berpikir, menyelesaikan masalah dan keahlian intelektual. Dengan diterapkannya model pembelajaran problem based learning maka diaharapkan pemahaman siswa terhadap materi pelajaran akan meningkat yang berdampak pada peningkatan hasil belajar, selain itu siswa juga belajar untuk memecahkan permasalahanpermasalahan yang sering ditemui di dunia nyata.

Menurut Munir (2012: 289), Video adalah teknologi penangkapan, perekaman, pengolahan, dan penyimpanan, pemindahan, dan perekonstruksian urutan gambar diam dengan menyajikan adegan-adegan dalam gerak secara elektronik.

Media video itu sendiri menurut Kustandi (2011:64) merupakan suatu media yang terdiri dari media visual yang disinkronkan dengan media audio, menggambarkan suatu objek yang bergerak bersama-sama dengan suara alamiah/suara yang sesuai sangat memungkinkan terjalinnya komunikasi dua arah antara guru dan anak didik di dalam frase belajar-mengajar. Media video dapat menyajikan informasi, memaparkan proses, menjelaskan konsep-konsep dengan rumit, mengajarkan ketrampilan, menyingkat/memperpanjang waktu dan mempengaruhi sikap.

Video dalam pembelajaran problem based learning membantu guru dalam menyampaikan informasi dan menyajikan permasalah secara audio visual sehingga siswa pada pendidikan dasar mendapatkan gambaran kongkret tentang permasalahan yang akan mereka pelajari dan pecahkan. 


\section{METODE}

Penelitian ini merupakan Penelitian Tindakan Kelas (Classroom Action Research) yang menerapkan Model pembelajaran problem based learning berbantuan video dengan tujuan utama untuk memecahkan masalah-masalah dalam kegiatan pembelajaran sehari-hari yang dialami oleh guru maupun siswa.

Model PTK secara garis besar terdapat empat tahapan yang lazim dilalui yaitu : (1). Perencanaan, (2). Pelaksanaan, (3). Pengamatan, (4). Refleksi.

Dalam kegiatan perencanaan meliputi : Menyusun rencana pembelajaran, menyiapkan bahan ajar media, lembar observasi, angket siswa, dan soal evaluasi. Pelaksanaan tindakan dalam penelitian ini terdiri atas tiga siklus. Siklus I dilaksanakan pada tanggal 2 November 2020, Siklus II pada tanggal 9 November 2020 dan siklus III pada tanggal 20 November 2020. Pengamatan dalam kegiatan ini observer monitoring dan evaluasi (monev) dilakukan bersamaan dengan pelaksanaan tindakan dengan menggunkan lembar observasi yang telah disiapkan. Hasil pelaksanaan tindakan kelas meliputi data tes dan non tes. Data tes berupa hasil evaluasi siswa. Data non tes berupa hasil pengamatan yang dicatat dalam lembar observasi. Refleksi dilakukan pada akhir pembelajaran, untuk memberikan gambaran kelemahan pada siklus I sehingga dapat dicari pemecahannya dan mempertahankan serta meningkatkan kelebihan yang terdapat pada siklus I.

\section{HASIL DAN PEMBAHASAN}

Penelitian tindakan kelas ini dilaksanakan di kelas III SD Negeri 05 Bantarbolang, Koordinator Wilayah Kec. Bantarbolang, Dinas Pendidikan dan Kebudayaan Kab. Pemalang. Penelitian tindakan kelas ini dilakukan dalam 3 siklus untuk menentukan bagaimana penerapan model pembelajaran problem based learning berbantuan video dapat meningkatkan hasil belajar siswa. Penerapan model pembelajaran problem based learning berbantuan video dilakukan dalam 5 langkah yaitu memberikan orientasi masalah pada siswa, mengorganisasi siswa untuk meneliti, mendampingi pengalaman individu/kelompok, mengembangkan dan menyajikan hasil, menganalisis dan mengevaluasi proses pemecahan masalah. Pada siklus I yang dilaksanakan pada hari Senin tanggal 2 November 2020 peneliti berpatokan dari hasil nilai ulangan harian siswa kelas III pada tema 3 Benda di Sekitarku subtema 1 Aneka Benda di Sekitarku pembelajaran kedua. Selanjutnya guru melakukan tindakan siklus I dengan cara memberi soal-soal evaluasi pada siswa. Dari pengerjaan soal evaluasi tersebut diperoleh data ketuntasan hasil belajar sebagai berikut:

Tabel 1. Hasil belajar siswa pada siklus I

\begin{tabular}{|c|c|c|}
\hline Ketuntasan & Frekuensi & Persentase (\%) \\
\hline Tuntas ( $\geq$ KKM 70) & 9 & 60 \\
\hline Belum Tuntas ( $\leq$ KKM 70) & 6 & 40 \\
\hline Rerata & \multicolumn{2}{|c|}{77} \\
\hline Nilai Tertinggi & \multicolumn{2}{|c|}{100} \\
\hline Nilai Terendah & \multicolumn{2}{|c|}{54} \\
\hline
\end{tabular}

Dari tabel 1 di atas dapat diketahui bahwa penerapan Model pembelajaran problem based learning berbantuan videobelum sepenuhnya dapat meningkatkan hasil belajar dan tingkat ketuntasan sesuai target yang direncanakan. Baru 9 siswa $(60 \%)$ dinyatakan tuntas ( $\geq$ KKM 70) dan 6 siswa (40 \%) dinyatakan belum tuntas ( $\leq \mathrm{KKM}$ 70), kemudian hasil belajar siswa kelas III SD Negeri 05 Bantarbolang baru mencapai rerata 77, dengan nilai tertinggi 100 dan nilai terendah 54 .

Berdasarkan refleksi pada siklus I, maka diputuskan untuk melanjutkan ke tahap siklus II.Hal ini dikarenakan belum mencapai ketuntasan klasikal yang diharapkan. 
Tindakan pembelajaran siklus II dilaksanakan hari Senin tanggal 9 November 2020 dengan pada tema 3 Benda di Sekitarku subtema 1 Aneka Benda di Sekitarku pembelajaran ke 3. Pelaksanaan tindakan siklus II sesuai dengan perencanaan sepert siklus I yaitu 1 kali pertemuan yang masing-masing dengan waktu 70 menit ( $2 \mathrm{x}$ pertemuan ). Hasil ketuntasan belajar siswa siklus II disajikan pada tabel di bawah ini :

Tabel 2. Hasil belajar siswa pada siklus II

\begin{tabular}{lcc}
\multicolumn{1}{c}{ Ketuntasan } & Frekuensui & Persentase (\%) \\
\hline Tuntas ( $\geq$ KKM 70) & 13 & 87 \\
\hline Belum Tuntas ( $\leq$ KKM 70) & 2 & 13 \\
\hline Rerata & 81 & \\
\hline Nilai Tertinggi & 100 & \\
\hline Nilai Terendah & 50 & \\
\hline
\end{tabular}

Berdasarkan tabel 2, nampak bahwa hasil belajar setelah penerapan Model pembelajaran problem based learning berbantuan videopada siklus II meningkat dengan rata-rata nilai 81 dibandingkan dengan hasil belajar pada siklus I yang hanya mencapai 77, dengan nilai tertinggi 100 dan nilai terendah 50. Terdapat 13 siswa (87 $\%$ ) yang dinyatakan tuntas ( $\geq$ KKM 70) dan 2 siswa (13\%) dinyatakan belum tuntas ( $\leq \mathrm{KKM} 70$ ). Hasil belajar yang sudah dianalisis oleh peneliti menunjukkan hasil yang memuaskan pada siswa kelas III SD Negeri 05 Bantarbolang karena hanya 2 siswa dari 15 siswa yang belum mencapai Kriteria Ketuntasan Minimal (KKM) yang ditentukan. Untuk siswa yang belum mecapai ketuntasan belajar, peneliti memberikan tugas remedial dengan bantuan guru kelas dan orang tua agar diawasi perkembangannya.

Setelah melakukan refleksi pada siklus II maka peneliti perlu melanjutkan pada siklus III. Hal ini dilakukan untuk mengetahuia sejauh mana penerapan Model pembelajaran problem based learning berbantuan video berhasil. Tidak hanya untuk meningkatkan hasil belajar siswa saja tetapi juga untuk mempertahankannya. Pada siklus III ini materi yang diajarkan yaitu tema 3 Benda di sekitarku subtema 1 Aneka Benda di Sekitarku pembelajaran ke 4. Kegiatan dilaksanakan pada hari Jumat tanggal 20 November 2020. Hasil belajar siswa siklus III dapat dilihat pada tabel di bawah ini :

Tabel 3. Hasil belajar siswa siklus III

\begin{tabular}{lcc} 
Ketuntasan & Frekuensi & Persentase (\%) \\
Tuntas ( $\geq$ KKM 70) & 13 & 87 \\
\hline Belum Tuntas ( $\leq$ KKM 70) & 2 & 13 \\
\hline Rerata & 82,67 & \\
\hline Nilai Tertinggi & 100 & \\
\hline Nilai Terendah & 60 & \\
\hline
\end{tabular}

Dari tabel 3 dapat dijelaskan bahwa siswa yang dinyatakan tuntas terdapat 13 siswa (87\%) dan 2 siswa (13\%) dinyatakan belum tuntas. Dengan nilai tertinggi 100 dan nilai terendah 60 dan rerata 82,67. Meskipun ketuntasan klasikal tidak mengalami peningkatan, namun untuk rerata nilai mengalami peningkatan sebanyak 1,67 point dari rerata 81 (siklus II) menjadi 82,67 (siklus III).

Hasil belajar siswa kelas III SD Negeri 05 Bantarbolang menggunakan metode pembelajaran video based leraning pada kondisi prasiklus, siklus I, siklus II, dan siklus III mengalami perubahan. Hasil belajar siswa pada kondisi prasiklus menunjukkan bahwa 10 dari 15 siswa belum mencapai ketuntasan belajar ( $\geq$ KKM 70). Hasil belajar pada siklus I mengalami perubahan yaitu 6 dari 15 siswa belum mencapai ketuntasan belajar ( $\geq$ KKM 70). Kemudian pada siklus II mengalami perubahan yaitu 2 dari 15 
siswa belum mencapai ketuntasan belajar ( $\geq$ KKM 70). Dan pada siklus III tidak mengalami perubahan dari siklus sebelumnya, yaitu 2 dari 15 siswa belum mencapai ketuntasan belajar ( $\geq$ KKM 70). Perbandingan ketuntasan hasil belajar siswa pada kondisi prasiklus, siklus I, siklus II, dan siklus III dapat dilihat pada tabel di bawah ini :

Tabel 4. Tabel Perbandingan Rekapitulasi Ketuntasan Hasil Belajar Kelas III Tema Benda di Sekitarku Subtema 1 Aneka Benda di Sekitarku Kondisi Prasiklus, Siklus I, Siklus II, dan Siklus III

\begin{tabular}{llllllllll} 
No. & Ketuntasan & \multicolumn{2}{c}{ Prasiklus } & \multicolumn{2}{c}{ Siklus I } & \multicolumn{2}{c}{ Siklus II } & \multicolumn{2}{c}{ Siklus III } \\
& & $\mathrm{f}$ & $\%$ & $\mathrm{f}$ & $\%$ & $\mathrm{f}$ & $\%$ & $\mathrm{f}$ & $\%$ \\
\hline 1. & Tuntas & 5 & 33 & 9 & 60 & 13 & 87 & 13 & 87 \\
\hline 2. & $\begin{array}{l}\text { Belum } \\
\text { Tuntas }\end{array}$ & 10 & 67 & 6 & 40 & 2 & 13 & 2 & 13 \\
\hline & Jumlah & 15 & 100 & 15 & 100 & 15 & 100 & 15 & 100 \\
\hline
\end{tabular}

Berdasarkan tabel 4 rekapitulasi ketuntasan hasil belajar di atas terjadi peningkatan jumlah siswa yang mengalami ketuntasan belajar. Terbukti pada kondisi awal siswa yang dinyatakan tuntas hanya 5 siswa. Setelah dilakukan tindakan pada siklus I jumlah siswa yang dinyatakan tuntas meningkat menjadi 9 siswa. Pada siklus II dan III jumlah siswa yang dinyatakan tuntas sebanyak 13 siswa. Hal ini terbukti dari pengaruh penerapan Model pembelajaran problem based learning berbantuan videoyang menarik dan sesuai dengan materi dapat meningkatkan hasil belajar. Dengan Model pembelajaran problem based learning berbantuan videodapat membuat siswa memahami materi yang disampaikan guru, sehingga hasil belajarpun meningkat.

\section{SIMPULAN}

Berdasarkan hasil dan pembahasan pada penelitian di atas dapat diambil kesimpulan bahwa : (1). Langkah-langkah model pembelajaran problem based learning berbantuan video yang terbukti dapat meningkatkan hasil belajar adalah memberikan orientasi masalah pada siswa, mengorganisasi siswa untuk meneliti, mendampingi pengalaman individu/kelompok, mengembangkan dan menyajikan hasil, menganalisis dan mengevaluasi proses pemecahan masalah. Penerapan model pembelajaran problem based learning berbantuan video dapat meningkatkan hasil belajar siswa kelas III SD Negeri 05 Bantarbolang tema 3 Benda di Sekitarku subtema 1 Aneka Benda di Sekitarku.Hal ini ditunjukkan dengan peningkatan hasil belajar dari tahap prasiklus hingga siklus III. Pada prasiklus siswa yang dinyatakan tuntas hanya 5 siswa (33\%) dan 10 siswa (67\%) dinyatakan belum tuntas. Pada siklus I terdapat 9 siswa $(60 \%)$ dinyatakan tuntas dan 6 siswa $(40 \%)$ dinyatakan belum tuntas. Pada siklus II terdapat 13 siswa (87\%) dinyatakan tuntas dan 2 siswa (13\%) dinyatakan belu tuntas. Pada siklus III terdapat 13 siswa (87\%) dinyatakan tuntas dan 2 siswa (13\%) dinyatakan belum tuntas.

\section{DAFTAR PUSTAKA}

Dimyati dan Mudjiono. (2006). Belajar dan Pembelajaran. Jakarta: PT Rineke Cipta

Ekawarna. (2013). Penelitian Tindakan Kelas. Jambi: GP Press Group

Komalasari, Kokom. (2013). Pembelajaran Kontekstul : Konsep dan Aplikasi. Bandung

: PT. Refika Adiatama

Munir. (2012). Multimedia Konsep \& Aplikasi dalam Pendidikan. Bandung :

Alfabeta

Purwanto Ngalim. (1990). Belajar Berhubungan Dengan Perubahan Tingkah Laku. 
SHEs: Conference Series 3 (3) (2020) 999- 1005

Jakarta: PT Rineka Cipta

Suprijono, Agus. (2013). Cooperative Learning Teori dan Aplikasi PAIKEM.

Yogyakarta: Pustaka Pelajar.

Suyatno.(2009). Menjelajah Pembelajaran Inovatif. Sidoarjo: Masmedia Buana Pusaka 